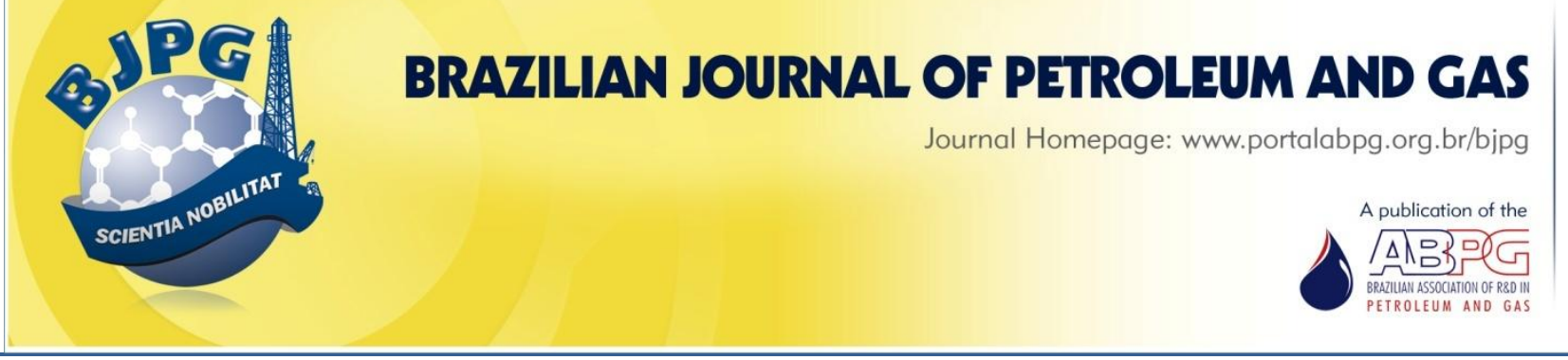

\title{
APPLICATION OF CENTRAL COMPOSITE ROTATIONAL DELINEATION (CCRD) IN THE STUDY OF BIODIESEL PROPERTIES
}

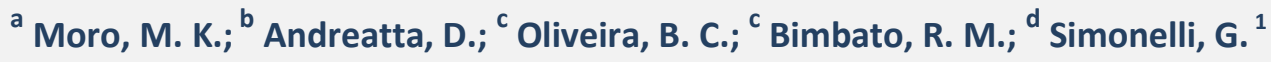 \\ ${ }^{a}$ Chemical Engineering Program, COPPE, Universidade Federal do Rio de Janeiro, Rio de Janeiro - RJ, Brazil \\ ${ }^{b}$ Post Graduate Program in Energy, PGEN, Universidade Federal do Espírito Santo, São Mateus - ES, Brazil \\ c Department of Chemical Engineering, Faculdades Integradas de Aracruz, Aracruz - ES, Brazil \\ ${ }^{d}$ Department of Science and Technology of Materials, DCTM, Universidade Federal da Bahia, Salvador - BA, Brazil
}

Received: 16.02.2017 / Revised: 29.10.2017 / Accepted: 30.10.2017 / Published on line: 21.12.2017

\begin{abstract}
In Brazil, biodiesel is produced from vegetable oils or fats. In this context, tallow is a raw material that commonly is used in the production of biodiesel due to its availability at a low cost. Despite of its advantages, biodiesel from tallow may cause plugging of filters in cars during cold seasons. A Composite Central Rotational Design of three independent variables (percentage of beef tallow, molar amount of methyl alcohol, and percent of $\mathrm{KOH}$ ) was used to evaluate acid number, kinematic viscosity at $40{ }^{\circ} \mathrm{C}$, density at $20^{\circ} \mathrm{C}$, and cold filter plugging point of the biodiesel produced by alkaline transesterification of different proportions of soybean oil and beef tallow. The results show that while the acid value was not affected by the independent variables, the percentage of beef tallow linearly affected density and kinematic viscosity. The biodiesel produced met ANP specifications, except for the cold filter plugging point in certain regions and during the coldest seasons in Brazil.
\end{abstract}

\section{KEYWORDS}

experiment design; biodiesel quality; beef tallow; ANP specifications; cold filter plugging point

\footnotetext{
${ }^{1}$ To whom all correspondence should be addressed.

Address: Rua Professor Aristides Novis, 02, Federação - Escola Politécnica da UFBA - $3^{\circ}$ andar, Departamento de Ciência e Tecnologia dos Materiais, Salvador - BA - Brazil.

ZIP Code: 40210-630 | Telephone: +55 71 3283-9854 |e-mail: gsimonelli@ufba.br doi:10.5419/bjpg2017-0016
} 


\section{INTRODUCTION}

Biodiesel is a biofuel that can be produced from different sources of triglycerides (ANP, 2017; Bilgin et al., 2015). Vegetable oils and animal fats are commonly used as sources of triglycerides in the production of this fuel (Balat \& Balat, 2010; Thangaraj, 2014). Soybean oil, bovine fat, and cotton oil are, in this order, the most used raw materials in Brazil in the production of biofuels (ANP, 2017).

When selecting the raw material to be used in the production biodiesel, one must consider the oil or fat that is most suitable for the conditions of each region of the Country. In certain cases, bovine fat presents the lowest cost (ANP, 2017; Demirbas, 2005; Iglesias \& Morales, 2012). However, soybean oil is preferred because bovine tallow normally produces a biodiesel with high viscosity, specific mass, and a cold filter plugging point (CFPP) (Basha et al., 2009; Bhuiya et al., 2015; Lebedevas et al., 2006; Moraes et al., 2008). These bovine tallow characteristics represent a problem to the industry because they produce fuels that are often considered unfit, failing to meet the specifications and parameters of quality established by the the National Agency of Petroleum, Natural Gas and Biofuels (ANP) in Brazil.

To solve this problem, Cunha (2008), Milli et al. (2011), and Oliveira et al. (2012) studied the production of biodiesel from mixtures of different vegetable oils and fats. Cunha (2008) studied the characterization of biodiesel produced with binary mixtures of soybean oil, beef tallow, and chicken fat. Milli et al. (2011) produced and characterized biodiesel from the mixture of soybean oil and bovine tallow, cotton oil and bovine tallow, and canola oil and bovine tallow. Working with adequate proportions of vegetable oil and animal fat, the biodiesel produced presented lower viscosity, specific mass, and a cold filter plugging point when compared to the biodiesel produced only from fats. Aiming at contributing to the previous studies, Oliveira et al. (2012) used an experimental planning to investigate the influence of molar amounts of alcohol, beef tallow/soybean oil ratio, and the percentage of $\mathrm{KOH}$ (catalyst) on the yield of raw materials to biodiesel. Tavares et al. (2017) studied the optimization of biodiesel production from frying oil and bovine tallow. The result obtained, indicated that the best conditions to reach $99.43 \%$ of ester content used a 9:1 solvent/feed molar ratio, $0.5 \%$ catalyst $(\mathrm{KOH})$, $70 \% / 30 \%$ frying oil/bovine tallow, and 35 seconds reaction time.

Several studies investigate the variable effects in the process to provide bases to the production of a quality and economically viable fuel. To achieve optimal conditions, these experiments used the Central Compound Rotational Delineation (CCRD) design, which allows the evaluation of the effect of one variable over another, reaching more reliable results. In addition, it is possible to identify the factors that most influence the production process.

In this context, this research proposes, through a three-variable Central Composite Rotational Delineation, to investigate the influence of the molar amount of methyl alcohol, bovine tallow / soybean oil ratio and catalyst percentage $(\mathrm{KOH})$ in some final properties - acidity index, kinematic viscosity at $40{ }^{\circ} \mathrm{C}$, density at $20^{\circ} \mathrm{C}$, and cold filter plugging point - of the produced biodiesel from transesterification of soybean oil and bovine tallow mixtures. The results of the final proprieties were compared to ANP specifications.

\section{MATERIALS AND METHODS}

To evaluate the influence of reaction conditions on the quality of the product, an experimental design was elaborated. The study was carried out using a CCRD with three variables: percentage of bovine tallow, molar amount of alcohol, and percentage of catalyst; all in relation to the mass of feedstock.

The technique of Central Composite Design (CCD) can be used to reduce the number of experimental points. The CCD is a design that requires a smaller number of tests and can be performed sequentially to obtain optimal process conditions (Rodrigues \& lemma, 2009).

The CCD consists of the combinations of the upper and lower levels of the factors (independent variables) as well as the addition of central points of the factors. The addition of axial points to the CCD results in a CCRD (Central Composite Rotational Delineation). The selection of the axial point can be done using $\pm \alpha$ points, where 
Table 1. Definition and levels of variables.

\begin{tabular}{ccccccc}
\hline Variables & Code & $\mathbf{- 1 . 6 8}$ & $\mathbf{- 1}$ & $\mathbf{0}$ & $\mathbf{1}$ & $\mathbf{1 . 6 8}$ \\
\hline \% Tallow & $\mathrm{x}_{1}$ & 10 & 22.14 & 40 & 57.85 & 70 \\
\% Catalyst & $\mathrm{x}_{2}$ & 1 & 1.2 & 1.5 & 1.79 & 2 \\
Alcohol (mol) & $\mathrm{x}_{3}$ & 3 & 4.21 & 6 & 7.78 & 9 \\
\hline
\end{tabular}

Notes: - \% of tallow and catalyst in relation to the mass of raw material

- Molar amount of alcohol to one mol of raw material.

Table 2. Experiments of the Central Composite Rotational Delineation.

\begin{tabular}{cccc}
\hline Test & $\mathbf{x}_{\mathbf{1}}$ & $\mathbf{x}_{\mathbf{2}}$ & $\mathbf{x}_{\mathbf{3}}$ \\
\hline $\mathbf{1}$ & 22.14 & 1.2 & 4.21 \\
$\mathbf{2}$ & 57.85 & 1.2 & 4.21 \\
$\mathbf{3}$ & 22.14 & 1.79 & 4.21 \\
$\mathbf{4}$ & 57.85 & 1.79 & 4.21 \\
$\mathbf{5}$ & 22.14 & 1.2 & 7.78 \\
$\mathbf{6}$ & 57.85 & 1.2 & 7.78 \\
$\mathbf{7}$ & 22.14 & 1.79 & 7.78 \\
$\mathbf{8}$ & 57.85 & 1.79 & 7.78 \\
$\mathbf{9}$ & 10 & 1.5 & 6 \\
$\mathbf{1 0}$ & 70 & 1.5 & 6 \\
$\mathbf{1 1}$ & 40 & 1 & 6 \\
$\mathbf{1 2}$ & 40 & 2 & 6 \\
$\mathbf{1 3}$ & 40 & 1.5 & 3 \\
$\mathbf{1 4}$ & 40 & 1.5 & 9 \\
$\mathbf{1 5}$ & 40 & 1.5 & 6 \\
$\mathbf{1 6}$ & 40 & 1.5 & 6 \\
$\mathbf{1 7}$ & 40 & 1.5 & 6 \\
\hline
\end{tabular}

Notes: - \% of tallow and catalyst in relation to the mass of raw material - Molar amount of alcohol to one mol of raw material.

$\alpha=(2 k) 1 / 4$ (Brasil, 2014; Cunha et al., 2009; Rodrigues \& lemma, 2009). In CCRD, the generalized polynomial equation, shown below, is the most appropriate model (Barros Neto, 2001):

$$
\begin{aligned}
\gamma_{i}= & \beta_{0}+\beta_{1} x_{1}+\beta_{2} x_{2}+\beta_{3} x_{3}+\beta_{4} x_{4}+ \\
& +\beta_{11} x_{1}^{2}+\beta_{22} x_{2}^{2}+\beta_{33} x_{3}^{2}+\beta_{44} x_{4}^{2}+ \\
& +\beta_{12} x_{1} x_{2}+\beta_{13} x_{1} x_{3}+\beta_{14} x_{1} x_{4}+ \\
& +\beta_{23} x_{2} x_{3}+\beta_{24} x_{2} x_{4}+\beta_{34} x_{3} x_{4}+\varepsilon_{i}
\end{aligned}
$$

Where: $x_{1}, x_{2}, x_{3}$, and $x_{4}$ are the variables related to the factors; $\beta 0$ (intersection point); $\beta_{1}, \beta_{2}, \beta_{3}$, and $\beta_{4}$ (refer to the linear effects); $\beta_{11}, \beta_{22}, \beta_{33}$, and $\beta_{44}$ (refer to the quadratic effects); and $\beta_{12}, \beta_{13}, \beta_{14}, \beta_{23}$, $\beta_{24}$, and $\beta_{34}$ (refer to the effects of double interaction) are the regression coefficients obtained by Ordinary Least Squares; and $\varepsilon_{\mathrm{i}}$ ( $\mathrm{i}=1,2$ $\ldots)$ is the experimental error. This equation was found through multiple regression using a statistical software.

Table 1 shows the variables and their respective values. To perform the Factorial Planning using a reduced number of experiments while maintaining the reliability of the results, 17 experiments were performed (Table 2). The experiments were: 3 tests at the central point to calculate the error, 6 axial tests, and 8 factorial tests. The experimental points were not replicated, but the three central points were used to estimate the pure error. 
The bovine tallow, used to produce the biodiesel samples, was supplied by Gran Vitória, located in the state of Espírito Santo, Brazil. All the reagents used in the synthesis of biodiesel and in the analysis of their properties were anhydrous.

To obtain biodiesel, $400 \mathrm{~g}$ of a mixture of soybean oil (Soya ${ }^{\circ}$ ) and bovine fat was accurately weighed. The bovine tallow was heated on an electric plate before being mixed with the oil. Inside a one liter beaker, the mixture was subjected to heating in a thermostatic bath at $60^{\circ} \mathrm{C}$ under constant stirring, using a mechanical stirrer coupled to the thermostatic bath.

The transesterification reaction was, then, carried out at $60{ }^{\circ} \mathrm{C}$ by adding anhydrous methyl alcohol (Synth ${ }^{\circ}$ ) and potassium hydroxide (Synth ${ }^{\circ}$ ) to the mixture of soybean oil and bovine fat inside the beaker. After 30 minutes of reaction, under the conditions defined for each test, the mixture was decanted in a separating funnel for 24 hours to form a glycerin-rich and a biodiesel-rich phase. After the separation phase, the biodiesel was washed, with distillated water at $90{ }^{\circ} \mathrm{C}$ and decanted for 2 hours, three times for removing its impurities. The biodiesel was dried in a laboratory stove at $105^{\circ} \mathrm{C}$ for 2 hours and accurately weighed (Garcia et al., 2011; Menezes et al., 2006; Teixeira et al., 2010). The biodiesel yield (\%) was calculated using the procedure adopted by Fadhil, Al-Tikrity, and Albadree (2015). Thus, Equation (2) was used.

Biodiesel yield $(w t, \%)=$

$=\frac{\text { Weight of purified biodiesel }}{\text { Weight of raw oil used }} \times 100$

The first analysis consisted in the determination of the acidity index by titrating a mixture of ethyl ether, ethyl alcohol, and biodiesel with sodium hydroxide $0.1 \mathrm{~N}$. For the solubilization of the biodiesel, $50 \mathrm{~mL}$ of ethyl ether with ethyl alcohol in a ratio of 2:1 $(\mathrm{v} / \mathrm{v})$, and about $2.5 \mathrm{~g}$ of the biodiesel sample were added. Then, the mixture was titled with a previously prepared $\mathrm{NaOH}$ solution, using 3 drops of phenolphthalein $1 \%$ as indicator. The volume of $\mathrm{NaOH}$ consumed in the titration was used to calculate the biodiesel acidity index, by Equation 3.
$I_{A}=\frac{\left(\mathrm{V}_{\mathrm{NaOH}} \times \mathrm{N}_{\mathrm{NaOH}} \times 56.1\right)}{\mathrm{m}_{\text {bio }}}$

Where $I_{A}$ is the acidity index, in $\mathrm{mg} \mathrm{KOH} / \mathrm{g} ; \mathrm{N}_{\mathrm{NaOH}}$ and $\mathrm{V}_{\mathrm{NaOH}}$ are, respectively, the molarity, in $\mathrm{mol} / \mathrm{L}$, and the volume, in $\mathrm{mL}$, of the $\mathrm{NaOH}$ solution consumed in the titration; and $\mathrm{m}_{\text {bio }}$ is the biodiesel mass, in grams.

A previously calibrated $5 \mathrm{~mL}$ pycnometer was used to determine the density. The calibration was carried out by the difference between the masses of the empty pycnometer and of the pycnometer filled up with distilled water. This allowed to discover the mass of water that is admitted by the pycnometer and, then, its real volume. After calibration, the biodiesel was cooled in iced water until reaching the temperature of $20^{\circ} \mathrm{C}$ and added to the pycnometer to measure the total mass.

The kinematic viscosity at $40{ }^{\circ} \mathrm{C}$ was measured using the Ostwald viscometer and water as reference. The flow time of $10 \mathrm{~mL}$ of each biodiesel sample was determined with the viscometer inside a thermostatic bath at $40{ }^{\circ} \mathrm{C}$. Then, the specific mass of each biodiesel sample at the same temperature was calculated.

The absolute viscosity, calculated by Equation 4, was converted to kinematic viscosity using Equation 5. In the equations, $\mu_{\text {bio }}$ and $v_{\text {bio }}$ are the absolute and kinematic viscosity; $\rho_{\text {bio }}$ is the specific mass of the biodiesel, all at $40{ }^{\circ} \mathrm{C}$; $t_{\text {bio }}$ and $t_{\mathrm{H} 2 \mathrm{O}}$ are the biodiesel and water flow time, respectively.

$\frac{\mu_{\text {bio }}}{\mu_{\mathrm{H}_{2} \mathrm{O}}}=\frac{\rho_{\text {bio }} \times t_{\text {bio }}}{\rho_{\mathrm{H}_{2} \mathrm{O}} \times \mathrm{t}_{\mathrm{H}_{2} \mathrm{O}}}$

$v_{\text {bio }}=\frac{\mu_{\text {bio }}}{\rho_{\text {bio }}}$

Finally, the CFPP of the biodiesel samples of different percentages of bovine tallow (test 1 : $22.14 \%$, test $13: 40 \%$, test $6: 57.85 \%$ and test 10 : $70 \%$ ) was analyzed at the National Institute of Technology (INT), following the methodology ASTM D - 6371.

All the characterization results of the biodiesel samples were included in the free to use program Action, version 2.4. Multiple regression and analysis of variance were used in the analysis of the results. 
Table 3. Characterization of biodiesel samples.

\begin{tabular}{cccccc}
\hline \multicolumn{7}{c}{ Dependent variables } \\
\hline Test & $\mathrm{I}_{\mathrm{A}}(\mathbf{m g ~ K O H} / \mathbf{g})$ & $\boldsymbol{\mu}\left(\mathbf{m m}^{2} / \mathbf{s}\right)$ & $\boldsymbol{\rho}\left(\mathbf{k g} \cdot \mathbf{m}^{-3}\right)$ & CFPP $\left.\mathbf{~}^{\circ} \mathbf{C}\right)$ & Yield (\%) \\
1 & 0.221 & 3.971 & 878.32 & 6 & 94.11 \\
2 & 0.249 & 4.134 & 875.46 & - & 93.20 \\
3 & 0.221 & 4.080 & 878.15 & - & 89.68 \\
4 & 0.249 & 4.370 & 875.15 & - & 89.76 \\
5 & 0.221 & 4.007 & 877.29 & - & 90.55 \\
6 & 0.166 & 4.225 & 871.97 & 14 & 90.15 \\
7 & 0.194 & 4.134 & 877.59 & - & 86.75 \\
8 & 0.221 & 4.334 & 872.65 & - & 87.57 \\
9 & 0.277 & 3.935 & 878.17 & - & 94.14 \\
10 & 0.332 & 4.388 & 872.19 & 14 & 93.02 \\
11 & 0.304 & 4.188 & 876.46 & - & 93.87 \\
12 & 0.304 & 4.134 & 874.41 & - & 87.22 \\
13 & 0.221 & 4.334 & 872.85 & 13 & 92.54 \\
14 & 0.388 & 4.261 & 874.09 & - & 82.69 \\
15 & 0.304 & 4.261 & 872.42 & - & 89.77 \\
16 & 0.304 & 4.243 & 874.72 & - & 90.45 \\
17 & 0.277 & 4.225 & 872.82 & - & 90.77 \\
\hline ANP & 0.50 & 3.0 to 6.0 & 850.0 to & variable (see & \\
\hline specifications & & 900.0 & Table 5) & \\
\hline
\end{tabular}

\section{RESULTS AND DISCUSSIONS}

After transesterification, the separation of the biodiesel and glycerin was simple and fast, forming two well-defined phases. The glycerin decantation was easy in samples with higher amounts of bovine tallow. No emulsion formation was observed during the biodiesel purification, indicating that the raw materials had low acidy index.

The results of chemical yield are presented in Table 3. The amount of tallow present in the raw material slightly influenced the yield; indicating that the bovine tallow used in this work did not present undesirable properties for transesterification, such as a high acid index. A high acidity index leads to formation of soaps and consequent yield reduction. The biodiesel yield results of this work were widely discussed in Oliveira et al. (2012).

Table 3 presents acidity index (IA), kinematic viscosity at $40{ }^{\circ} \mathrm{C}(\mu)$, density at $20^{\circ} \mathrm{C}(\rho)$, cold filter plugging point (CFPP), and biodiesel yield for the experimental test according to the factorial design.
In the CCRD, based on the three central points, the experimental errors of acidity index, kinematic viscosity, and density were, respectively, $0.012 \mathrm{mg}$ $\mathrm{KOH} . \mathrm{g}^{-1}, 0.014 \mathrm{~mm}^{2} . \mathrm{s}^{-1}$, and $1.015 \mathrm{~kg} . \mathrm{m}^{-3}$.

The coefficients of the analyzed variables and their respective main and interaction effects for the measured proprieties are shown in Table 4, generated by the Action software. By means of the regression coefficients on Table 4, theoretical mathematical models were obtained to estimate biodiesel properties. However, to simplify the equations, the parameters with $p$-values greater than 0.05 were removed from the models, since they have little to no influence on the final results. Therefore, the statistical data were recalculated based only on significant factors.

ANP regulates, for the acidity index, the maximum limit of $0.5 \mathrm{mg} \mathrm{KOH} . \mathrm{g}^{-1}$ (Brasil, 2014) and all the samples had an acid value below this limit. According to Table 4, none of the terms had a significant influence on the acidity index, considering a 95\% confidence interval ( $p$-value greater than 0.05 ). Thus, the studied variables and their interactions did not affect the acidity index. 
Table 4. Estimation of effects and regression coefficients for acid number, kinematic viscosity at $40{ }^{\circ} \mathrm{C}$ and specific mass at $20^{\circ} \mathrm{C}$ at a confidence interval of $95 \%$.

\begin{tabular}{|c|c|c|c|c|c|c|c|c|c|}
\hline \multicolumn{10}{|c|}{ Coefficients } \\
\hline \multirow[t]{2}{*}{ Preditor } & \multicolumn{3}{|c|}{ Regression coefficient } & \multicolumn{3}{|c|}{ Standard deviation } & \multicolumn{3}{|c|}{ P-value } \\
\hline & $I_{A}$ & $\mu$ & $\rho$ & $I_{A}$ & $\mu$ & $\rho$ & $I_{A}$ & $\mu$ & $\rho$ \\
\hline Intercept & 0.301 & 4.246 & 873.255 & 0.047 & 0.047 & 0.877 & 0.0006 & 0.0001 & 0.0001 \\
\hline$x_{1}(L)$ & 0.008 & 0.119 & -1.917 & 0.022 & 0.022 & 0.412 & 0.702 & 0.001 & 0.003 \\
\hline$x_{2}(L)$ & 0.002 & 0.035 & -0.215 & 0.022 & 0.022 & 0.412 & 0.929 & 0.162 & 0.619 \\
\hline$x_{3}(L)$ & 0.010 & 0.001 & -0.404 & 0.022 & 0.022 & 0.412 & 0.657 & 0.942 & 0.364 \\
\hline$x_{1}(Q)$ & -0.016 & -0.039 & 0.892 & 0.024 & 0.024 & 0.454 & 0.531 & 0.161 & 0.097 \\
\hline$x_{2}(Q)$ & -0.016 & -0.039 & 0.983 & 0.024 & 0.024 & 0.454 & 0.531 & 0.161 & 0.073 \\
\hline$x_{3}(Q)$ & -0.016 & 0.008 & 0.284 & 0.024 & 0.024 & 0.454 & 0.531 & 0.738 & 0.553 \\
\hline$x_{1}: x_{2}$ & 0.010 & 0.013 & 0.031 & 0.028 & 0.029 & 0.538 & 0.731 & 0.659 & 0.955 \\
\hline$x_{1}: x_{3}$ & -0.010 & -0.004 & -0.549 & 0.028 & 0.029 & 0.538 & 0.731 & 0.882 & 0.346 \\
\hline$x_{2}: x_{3}$ & 0.003 & -0.013 & 0.181 & 0.028 & 0.029 & 0.538 & 0.908 & 0.659 & 0.747 \\
\hline $\mathbf{x}_{1}: \mathbf{x}_{2}: \mathbf{x}_{3}$ & 0.010 & -0.018 & 0.066 & 0.028 & 0.029 & 0.538 & 0.731 & 0.559 & 0.905 \\
\hline
\end{tabular}

The low values of acidity index indicate that the feedstock had low content of free fatty acids, since the acidity index of the fuel is directly related to the fatty acids in the raw material (Fernando et al. 2005). The raw materials used presented good quality, not requiring a pre-treatment.

Moraes et al. (2008) obtained a biodiesel with an acidity index above the maximum limit, $0.7 \mathrm{mg}$ $\mathrm{KOH} . \mathrm{g}^{-1}$, in the methyl transesterification of pure bovine tallow using $\mathrm{KOH}$ as catalyst. This value was close to the acidity index, $0.6 \mathrm{mg} \mathrm{KOH} . \mathrm{g}^{-1}$, of the raw material used by the author.

Similarly, the coefficients of the variables analyzed for kinematic viscosity and their respective main and interaction effects are also presented in Table 4. Considering a confidence interval of $95 \%$, only the linear term of the tallow concentration influenced significantly the kinematic viscosity. Based only on the significant factor, Equation 6 is the reduced model, which describes the kinematic viscosity, as a function of the coded variable.

Kinematic viscosity at $40{ }^{\circ} \mathrm{C}=4.19+0.119 \mathrm{x}_{1}$

The regression was statistically significant, since the analysis of the variance indicated a Fcalc higher, about 6.3 times, than the tabulated value. According to the coefficient of determination $\left(R^{2}\right)$, the model explains how $65.89 \%$ of the viscosity data vary with the reaction conditions. Although the model does not fully represent the viscosity behavior, it provides some important information such as that the amount of bovine tallow is the variable that most affects fuel viscosity.

Equation 7 indicates that the fuel viscosity increase is directly related to the proportion of tallow in the feedstock. This result is consistent since animal fats have a higher saturation degree than vegetable oils, which proportionally increases the viscosity of biodiesel.

Despite these results, even for high proportions of bovine tallow, viscosity values were within the ANP specifications, between 3.0 and $6.0 \mathrm{~mm}^{2} \mathrm{~s}^{-1}$ (Brasil, 2014). Cunha et al. (2009) also achieved a fuel within the ANP limit in the methyl transesterification of pure bovine tallow, producing a biodiesel with kinematic viscosity equal to 5.3 $\mathrm{mm}^{2} \mathrm{~s}^{-1}$.

In regards to the specific mass, the coefficients of the analyzed variables and their respective main and interaction effects are also presented in Table 4. Only the linear term of the tallow concentration influenced significantly the kinematic viscosity, considering the $95 \%$ confidence interval. Based solely on tallow concentration being the significant factor, Equation 7 is the reduced model that 
describes the specific mass, as a function of the coded variable.

Density at $20^{\circ} \mathrm{C}=874.98-1.91 \mathrm{x}_{1}$

The regression was statistically significant, since the analysis of the variance indicated an $F_{\text {calc }}$ higher, about 4.7 times, than the tabulated values. According to the coefficient of determination $\left(R^{2}\right)$, the model explains how $58.81 \%$ of the density data varies with the reaction conditions. Although the model does not fully represent the density behavior, it provides the important information that the amount of bovine tallow in the feedstock is the variable that most affects density.

The strong relation observed in Equation 8 occurs because the density of the fuel varies according to the density used in the reaction (Moraes et al, 2008). The higher the tallow amount in the feedstock, the lower the density of biodiesel, since bovine tallow has a density lower than soybean oil. Alcantara et al. (2000) found 890.5 $\mathrm{kg} \cdot \mathrm{m}^{-3}$ and $881.5 \mathrm{~kg} \cdot \mathrm{m}^{-3}$ of density of soybean oil and bovine tallow, respectively.

The density for all samples were within the ANP limits, between 850 and $900 \mathrm{~kg} \cdot \mathrm{m}^{-3}$ (Brasil, 2014). Moraes et al. (2008) performed the transesterification reaction with bovine tallow and methanol in the presence of $\mathrm{KOH}$ and obtained a biodiesel with density $872 \mathrm{~kg} \cdot \mathrm{m}^{-3}$, also within the ANP parameters. Milli et al. (2011) produced biodiesel samples with a density of 887 to 878 $\mathrm{kg} \cdot \mathrm{m}^{-3}$, varying inversely with the proportions of tallow, 10 to $40 \%$.

The last parameter investigated was the cold filter plugging point which has a maximum limit fixed by ANP for each month of the year, according to Table 5. For the states not contemplated in the table, the CFPP should be a maximum of $19^{\circ} \mathrm{C}$.
For CFPP analysis, the samples from the 1, 6, 10, and 13 trials were selected, as they presented the highest yields in biodiesel production (Oliveira et al., 2012); and, for each of them, a different proportion of bovine tallow/raw material was used in the reaction, as shown in Table 2. This allowed the evaluation of the PEFF in different bovine tallow concentrations, as shown in Table 3 .

As expected, the higher the amount of tallow in the raw material is, the higher the cold filter plugging point of the fuel will be. In the first region of Table 5, SP-MG-MS, from November to March, all biodiesel samples were within the ANP limits. In the coldest months, from April to October, only the samples with a sebum percentage of up to $22.14 \%$ were within the legislation.

For the second region, GO - DF - MT - ES - RJ, all samples fitted within the ANP limits in the months of October to April, and from May to September only the samples with a tallow percentage lower than $22.14 \%$ fitted in ANP limits.

For the third region, PR - SC - RS, all samples were conformed to ANP limits in the months from November to March. Only the samples with tallow percentage of up to $22.14 \%$ fitted in the ANP specifications for April and October, and none of them met the specifications from May to September. For the states not contemplated in Table 5, all samples were according ANP specifications throughout the year.

Moraes et al. (2008) and Cunha et al. (2009) obtained samples of methyl biodiesel, produced from bovine tallow with a cold filter plugging point close to the values found in this study. Both found the CFPP to be $14.3^{\circ} \mathrm{C}$. According to Moraes et al. (2008), this fuel should not be used in regions where the temperature is relatively low.

Table 5. ANP especifications for CFPP (Brasil, 2014).

\begin{tabular}{ccccccccccccc}
\hline \multicolumn{10}{c}{ Maximum limit, oC } \\
\hline $\begin{array}{c}\text { States } \\
\text { SP-MG- }\end{array}$ & jan & feb & mar & apr & may & jun & jul & aug & sep & oct & nov & dec \\
$\begin{array}{c}\text { MS } \\
\text { GOF- }\end{array}$ & 14 & 14 & 14 & 12 & 8 & 8 & 8 & 8 & 8 & 12 & 14 & 14 \\
$\begin{array}{c}\text { MT-ES-RJ } \\
\text { PR-SC-RS }\end{array}$ & 14 & 14 & 14 & 14 & 10 & 10 & 10 & 10 & 10 & 14 & 14 & 14 \\
\hline
\end{tabular}


Thus, the mixtures recommended for fuel production vary according to the season of year and the region where the biodiesel will be used. The biodiesel produced from mixture of raw materials has its use limited only by the CFPP in some states, since the other properties conformed to the ANP requirements.

The amount of bovine tallow influenced the values of density at $20^{\circ} \mathrm{C}$, kinematic viscosity at $40^{\circ} \mathrm{C}$, and cold filter plugging point of the biodiesel. A density at $20^{\circ} \mathrm{C}$ of biodiesel decreased with the increase in the amount of bovine tallow in the feedstock. This is because the density of the bovine tallow biodiesel is lower than the density of the soybean oil one. The kinematic viscosity at $40^{\circ} \mathrm{C}$ of biodiesel is higher when the percentage of bovine tallow increases in the feedstocks. This is because the kinematic viscosity of bovine tallow biodiesel is higher than that of biodiesel from soybean oil. CFPP increased from $6^{\circ} \mathrm{C}$ to $14^{\circ} \mathrm{C}$ when the amount of bovine tallow ranged from $22.14 \mathrm{wt} \%$ (test 1) to $57.85 \mathrm{wt} \%$ (test 6). By increasing the amount of bovine tallow to $70 \%$ (test 10 ) the CFPP remained at $14^{\circ} \mathrm{C}$.

The best composition to obtain a product within ANP specifications was $22.14 \mathrm{wt} \%$ bovine tallow and 77.26 wt\% soybean oil (test 1). In this composition, the biodiesel produced with $1.2 \%$ of catalyst, $60^{\circ} \mathrm{C}$ and $4.21: 1$ alcohol/oil molar ratio presented CFPP of $6{ }^{\circ} \mathrm{C}$. This value of CFPP is favorable to the use of biodiesel in SP, MG, MS, $\mathrm{GO}, \mathrm{DF}, \mathrm{MT}, \mathrm{ES}$, and RJ in all months of the year. Nevertheless, such values are not suitable for the third region (PR - SC - RS) from May to September.

\section{CONCLUSIONS}

After studying the effects of catalyst type and concentration, methanol/oil molar ratio, methanol/co-solvent molar ratio, agitation rate, and reaction temperature, the best composition (22.14\% bovine tallow and $77.26 \%$ soybean oil) to obtain a product within ANP specifications was achieved with $1.2 \mathrm{wt} \% \mathrm{KOH}, 4,21: 1$ as methanol/oil molar ratio, and at $60^{\circ} \mathrm{C}$.

\section{REFERENCES}

Alcantara, R.; Amores, J.; Canoira, L.; Fidalgo, E.; Franco, M. J.; Navarro, A. Catalytic production of biodiesel from soy-bean oil, used frying oil and tallow. Biomass and Bioenergy, v.18, p. 515-527, 2000. https://doi.org/10.1016/S0961-9534(00)00014-3

ANP. Agência Nacional do Petróleo, Gás Natural e Biocombustíveis. Available at: http://www.anp.gov.br. Accessed on: 02 January 2017. (in Portuguese).

Balat, M.; Balat, H. Progress in biodiesel processing. Applied Energy, v.87, p. 1815-1835, 2010. https://doi.org/10.1016/i.apenergy.2010.01.012

Barros Neto, B.; Scarmínio, I. S.; Bruns, R. E. Planejamento e otimização de experimentos. 3. ed. Campinas: Editora Unicamp, 2001. 300p. (in Portuguese)

Basha, S. A.; Gopal, K. R.; Jebaraj, S. A review on biodiesel production, combustion, emissions and performance. Renewable and Sustainable Energy Reviews, v. 13, p. 1628-1634, 2009.

https://doi.org/10.1016/i.rser.2008.09.031

Bhuiya, M. M. K; Rasul, M. G.; Khan, M. M. K.; Ashwath, N.; Azad, A. K. Prospects of 2nd generation biodiesel as a sustainable fuel - part: 1 selection of feedstocks, oil extraction techniques and yield technologies. Renewable and Sustainable Energy Reviews, v.55, p. 1109-1128, 2015. https://doi.org/10.1016/j.rser.2015.04.163

Bilgin, A.; Gulum, M.; Koyuncuoglu, I.; Nac, E.; Cakmak, A. Determination of transesterification reaction parameters giving the lowest viscosity waste cooking oil biodiesel. Procedia - Social and Behavioral Sciences, v.195, p. 2492-2500, 2015. https://doi.org/10.1016/j.sbspro.2015.06.318

Brasil. Agência Nacional de Petróleo, Gás Natural e Biocombustíveis. Resolução ANP $\mathbf{N}^{\circ} \mathbf{4 5}$, de 25/08/2014. Diário Oficial da União da República do Brasil, Brasília, DF, 26 ago. 2014. (in Portuguese)

Cunha, M. E. Caracterização de biodiesel produzido com misturas binárias de sebo bovino, óleo de frango e óleo de soja. 86f. Dissertação de mestrado. Programa de Pós-Graduação em Química, Universidade Federal do Rio Grande do Sul, 2008. (in Portuguese) 
Cunha, M. E.; Krause, L. C.; Moraes, M. S. A.; Faccini, C. S.; Jacques, R. A.; Almeida, S. R.; Rodrigues, M. R. A.; Camarão, E. B. Beef tallow biodiesel produced in a pilot scale. Fuel Processing Technology, v.90, p. 570-575, 2009.

https://doi.org/10.1016/i.fuproc.2009.01.001

Demirbas, A. Biodiesel production from vegetable oils via catalytic and non-catalytic supercritical methanol transesterification methods. Progress in Energy and Combustion Science, v.31, p. 466-487, 2005.

https://doi.org/10.1016/j.pecs.2005.09.001

Fadhil, A. B., Al-Tikrity, E. T., Albadree, M. A. Transesterification of a novel feedstock, Cyprinus carpio fish oil: Influence of co-solvent and characterization of biodiesel. Fuel, v. 162, p. 215223, 2015. https://doi.org/10.1016/i.fuel.2015.09.001

Fernando, S.; Karra, P.; Hernandez, R.; Jha, S. K. Effect of incompletely converted soybean oil on biodiesel quality. Energy, v.32, p. 844-851, 2005. https://doi.org/10.1016/i.energy.2006.06.019

Garcia, M.; Gonzalo, A.; Sánchez, J. L.; Arauzo, J.; Simões, C. Methanolysis and Ethanolysis of animal fats: a comparative study of the influence of alcohols. Chemical Industry \& Chemical Engineering Quarterly, v.17, p. 91-97, 2011. https://doi.org/10.2298/CICEQ100224058G

Iglesias, J.; Morales, G. Biodiesel from waste oils and fats. In: Advances in biodiesel production: processes and technologies, 2012, pp.154-178. https://doi.org/10.1533/9780857095862.2.154

Lebedevas, S.; Vaicekauskas, A.; Lebedeva, G.; Makareviciene, V.; Janulis, P.; Kazancev, K. Use of waste fats of animal and vegetable origin for the production of biodiesel fuel: quality, motor properties, and emissions of harmful components. Energy Fuels, v.20, p. 2274-2280, 2006. https://doi.org/10.1021/ef060145c

Menezes, E. W.; Silva, R.; Cataluña, R.; Ortega, R. J. C. Effect of others and ether/ethanol additives on the physicochemical properties of diesel fuel on engine tests. Fuel, v.85, p. 815-822, 2006.

https://doi.org/10.1016/i.fuel.2005.08.027
Milli, B. B.; Gripa, D. C.; Simonelli, G; Martins, M. O. D. Produção de biodiesel a partir da mistura de sebo bovino com óleo vegetal. Enciclopédia Biosfera, v.7, p. 1-26, 2011.

Moraes, M. S. A.; Krause, L. C.; Cunha, M. E.; Faccini, C. S.; Menezes, E. W.; Veses, R. C.; Rodrigues, R. A.; Camarão, E. B. Tallow biodiesel: properties evaluation and consumption tests in a diesel engine. Energy \& Fuels, v. 22, p. 1949-1954, 2008. https://doi.org/10.1021/ef7006535

Oliveira, B. C.; Andreatta, D.; Moro, M. K.; Bimbato, R. M.; Simonelli, G. Produção de biodiesel a partir da mistura de óleo de soja e sebo bovino. Enciclopédia Biosfera, v.8, p. 2309-2320, 2012.

Rodrigues, M. I.; lemma, A. F. Planejamento de experimentos e otimização de processos. 2. ed. São Paulo: Cáritas, 2009. 357 p. (in Portuguese).

Tavares, D. C., Júnior, H. M., Santos, L. O., Mendes, M. F. Optimization of biodiesel production from frying oil and bovine tallow. Brazilian Journal of Petroleum and Gas, v. 11, n. 2, 2017. https://doi.org/10.5419/bjpg2017-0006

Teixeira; L. S. G.; Couto, M. B.; Souza, G. S.; Filho, M.; Assis, J. C. R.; Guimarães, P. R. B.; Pontes, L. A. M.; Almeida, S. Q.; Teixeira, J. S. R. Characterization of beef tallow biodiesel and their mixtures with soybean biodiesel and mineral diesel fuel. Biomass and Bioenergy, v.34, p. 438-441, 2010. https://doi.org/10.1016/j.biombioe.2009.12.007

Thangaraj, B.; Ramachandran, K. B.; Raj, S. P. Homogeneous catalytic transesterification of renewable azadirachta indica (neem) oil and its derivatives to biodiesel fuel via acid/alkaline esterification processes. International Journal of Renewable Energy \& Biofuels, Article ID 515961, p. 1-11, 2014. 